\title{
Public Debt and Economic Growth in Niger: An Autoregressive Distributed Lag Approach
}

\author{
Issoufou Oumarou ${ }^{1}$ \\ ${ }^{1}$ Ph.D., Faculté de droit d'économie et de gestion, Département d'économie et gestion, Université de \\ Tahoua, Tahoua, NIGER
}

\author{
Article Info \\ Article history: \\ Received: 19 July 2020 \\ Revised: 26 September 2020 \\ Accepted: 28 October 2020
Keywords:
Economic Growth,
Niger;
Public Debt;
Auto Regressive Distributed
Lag (ARDL) \\ JEL: C32; E31; F43; H63; \\ O11. \\ Paper Type : \\ Review Article \\ Corresponding Author: \\ Issoufou Oumarou \\ Email: \\ oumar1911@yahoo.com \\ ORCID: \\ https://orcid.org/0000-0002- \\ 7950-5612
}

\begin{abstract}
Purpose: The aim of the paper is to examine the existence or not of a long run or a short run relationship between public debt and economic in Niger and investigate the significance of this relationship.

Approach/Methodology/Design: The study first applied time series econometrics tests such as Augmented Dickey-Fuller (ADF) unit root test, Bound cointegration test and Auto Regressive Distributed Lag (ARDL) on annual data obtained from the International monetary fund (IMF) and the West African States Central Bank (BCEAO). The observations cover the period from 1970 to 2019. The study then performed some residual tests including serial correlation, normality and heteroskedasticity for the accuracy of the prediction of the model.

Findings: The empirical results showed no long run relationship between public debt and economic growth in Niger. The short run analysis revealed that public debt and budget balance have short run causal effects on economic growth in Niger. The coefficients are significant at 10\% significance level. Practical Implications: This article gives valuable information to Niger policy makers regarding the effects of public debt on Niger economic growth. The article highlights the effects that public debt has on economic growth in Niger in the short and long run. Therefore helping policy makers decide whether to increase or reduce the borrowing trend.

Originality/value: The results of the paper give valuable information on the relationship that public debt may have with economic growth in Sub Saharan African countries with the similar macroeconomic indicators with Niger.
\end{abstract}

\section{Introduction}

Located in the heart of the Sahel, Niger is a vast country with an economy that depends essentially on agriculture which represents $40 \%$ of its Gross domestic product (GDP). The economy of Niger has been marked in recent years by economic performances characterized by a growth of almost 5.2\% in 2018 and a significant improvement in the business climate (World Bank, 2019). The country's debt as percentage of Gross domestic product (GDP), however continue to increase. In 2018 Niger's debt reached $45 \%$ of its GDP. This has led the the International monetary fund to warn Niger government on the increasing trend of Niger's debt ratio (IMF, 2019). The objective of this study is to investigate if these massive debts have an impact on the economic growth of Niger.

In order to reach its objective, the present study applied time series econometrics tests such as Augmented Dickey-Fuller (ADF) unit root test to determine the series integration order, Bound 
cointegration test to check the existence of long-run relationship between the research variables and Auto Regressive Distributed Lag (ARDL) estimation. The tests are performed on annual data obtained from the International monetary fund (IMF) and the West African States Central bank (BCEAO). The study also performed some residual tests including serial correlation, normality and heteroskedasticity for the accuracy of the prediction of the model.

\section{Literature Review}

Dal \& Phillip (2020) used Vector Error Correction Model (VECM) on data of Nigeria from the period covering 1980 - 2016. The empirical results revealed that domestic debt has a statistically significant positive relationship with economic growth in the long run while external debt has a negative relationship with economic growth. The coefficients are not statistically significant. Muhammad \& Ihtsham (2020) investigated the nonlinear relationships between public debt and economic growth of Pakistan. The article used Autoregressive distributed lag approach on time series data to estimate the short term and long term effects of debt on economic growth in Pakistan. The paper also estimated the growth maximizing level of debt. The empirical results revealed that the optimal level of public debt is $60 \%$ of GDP. The results also indicated that a raise in government borrowings will increase economic growth in Pakistan in the long term. But in the short term, an increase of public debt will improve economic growth.

Eneida (2018) investigated the connection between public debt and economic growth in Albania in post-dictatorships used annual data obtained from the Ministry of Finance, the Bank of Albania and the International Monetary Fund. The empirical results showed no significant relationship between public debt and economic growth. The results revealed that shifting the workforce from low productivity to high productivity, prudent fiscal and monetary policies, sustainability of the macroeconomic situation, and steady growth of investment have significant effects on economic growth.

Muhammad et al. (2017) used Autoregressive Distributed lag analysis to investigate the impact of Malaysian Government debt on sustainable growth. The study is conducted over the period 1970 - 2015. The empirical results showed a positive significant short term connection between government debt and sustainable economic growth. The results also indicated a unidirectional causality between government debt and sustainable economic growth. Finally, the article found no evidence of significant impact of government debt on sustainable economic growth.

Ndubuisi (2017) used secondary data of Gross Domestic Product, External debt services, external debt stock, external reserve, and exchange rate to investigate the effects of external debt on economic growth of Nigeria. The paper used some econometrics tests such as the Augmented Dickey-Fuller unit root test, Johansen Cointegration test and error correction mechanism. The empirical results revealed unidirectional causality between external debt and GDP. Mhlaba \& Phiri (2017) used Autoregressive distributed lag model to investigate the long term and shortterm impacts of public debt on South African economic growth. The paper employed data covering the period 2002 - 2016. The paper split the data in two periods 2002-2007 and 2007- 
2016. The empirical results revealed negative long term debt -growth relationship and evidence of a positive short term relationship between the research variables specifically in the period 2007-2016.

Siew \& Yan (2015) used time series analysis and correlation test on annual data from Malaysia to investigate if public debt contributes to economic growth in Malaysia. They used data over the period 1991 to 2013. The study results revealed that public debt has a negative impact on Gross Domestic Product in the long run. The results also indicate that budget deficit, government consumption and external debt service are a decreasing function of GDP. Stella (2015) used a combination of time-series and cross-section data from the period 1981-2014 to investigate the common impact of government debt on GDP growth in the Europe union countries. The empirical results revealed a positive and statistically significant effect of debt on economic growth.

\section{Methodology and Procedures}

\subsection{Research data}

The current study used time series annual data obtained from the International monetary fund (IMF) and the West African States Central Bank (BCEAO). The observations cover the period from 1970 to 2019. The logarithm of Gross domestic product (GDP) is used as proxy for economic growth. Whereas, public debt in percentage of GDP, budget balance in percentage of GDP, Government consumption in percent of GDP and logarithm of the external debt service are respectively used as proxy for Public Debt (PD), Budget Balance (BB), Government Consumption (GC) and External Debt Service (EDS). Table 1 shows the research variables descriptive statistics.

Table 1: Research Variables Descriptive Statistics

\begin{tabular}{lllllll}
\hline Variables & Obs & Mean & Median & Maximum & Minimum & Std. Dev. \\
\hline EG (economic growth) & 50 & 21.6425 & 21.4983 & 22.9682 & 20.29235 & 0.7110 \\
PD (public debt) & 50 & 46.9316 & 44.2450 & 109.250 & 8.11000 & 27.829 \\
BB (budget balance) & 50 & -3.5891 & -3.61541 & 1.5828 & -10.6400 & 2.7009 \\
GC (gov. consumption) & 50 & 13.5398 & 14.2081 & 17.8887 & 8.168108 & 2.6783 \\
EDS (external debt service) & 50 & 17.6209 & 17.8956 & 19.3172 & 14.6000 & 1.2420 \\
\hline
\end{tabular}

Source: Author's calculation based on data from the IMF and BCEAO

Table 1 indicates that during the study period the national budget of Niger is mostly in deficit with an average of -3.59 as percentage of Niger Gross Domestic Product. The table also indicates that, on average the mean of public debt to GDP is 46.9316 and the budget balance to GDP is -3.5891 . The data also revealed about $13.5 \%$ of government consumption to GDP. The indicators of external debt service display a moderate fluctuation in variability. The range of external debt service in the sample is going from $14.6 \%$ to $19.3 \%$. 


\subsection{Methodology}

The current paper adopts a three-step econometrics approach to examine the significance of the relationship between public debt and economic growth in Niger. The study begins by checking the correlation among the research variables. After the correlation test, the Augmented DickeyFuller (ADF) unit root test is applied to verify the integration order of the research variables. Having established the integration order of the research variables, the appropriate cointegration test is applied in second step for testing the presence of cointegration relationship between the research variables. If the variables are cointegrated, there is a long run relationship among the variables. In third step, based on the findings of the second step, the appropriate short run and long run models are estimated. Finally, further residual tests including serial correlation, normality and heteroskedasticity tests were performed for the accuracy of the prediction of the model.The study used a basic debt-growth model on annual data to investigate the significance of the relationship between public debt and economic growth in Niger. The model consists of a set of indicators of debt burden with a proven impact on economic growth. The equation of the model used is given below:

$$
E G_{t}=\alpha+\beta_{1} P D_{t}+\beta_{2} B B_{t}+\beta_{3} G C_{t}+\beta_{4} E D S_{t}+\mu_{t}
$$

Where: EG represents economic growth, PD stands for public debt, BB stands for budget balance, GC stands for government consumption, EDS stands for external debt service and alpha and are respectively the intercept and error term. For the model specification and the number of lags to use in the model, information criteria are used to determine the optimal number. Table 2 provides the information criterion selection result.

Table 2: Information Criterion Selection Result

\begin{tabular}{lc}
\hline \multicolumn{1}{c}{ VAR system estimates } & value \\
\hline Determinant resid covariance (dof adj.) & 1.313187 \\
Determinant resid covariance & 0.357379 \\
Log likelihood & -315.8502 \\
Akaike information criterion & 15.45209 \\
Schwarz information criterion & 17.59618 \\
\hline
\end{tabular}

Source: Author's calculation

Table 2 shows that the value of the Akaike information criterion (AIC) (15.45209) is lower than the value of the Schwarz information criterion (SIC) (17.59618), hence the number of lags to be considered for the model is selected according to the results provided by the Akaike Information Criterion (AIC) and designed by $\mathrm{k}$. The information criteria suggest a model with a constant without trend for the variables. Since we are using annual data, in order to avoid spurious regression, we started the lag length selection by including a maximum of 4 lags. The Akaike Information Criterion suggests a lag length of $\mathrm{k}=4$ for the model. Table 3 gives the optimal lag selected for the model by the information criteria. 
Table 3 Model Optimal Lag Selection

\begin{tabular}{cclccc}
\hline Lag & LogL & FPE & AIC & SC & HQ \\
\hline 0 & -503.2459 & 2719.755 & 22.09765 & 22.29641 & 22.17211 \\
1 & -317.1427 & $2.487431^{*}$ & 15.09316 & $16.28575^{*}$ & $15.53991^{*}$ \\
2 & -301.6710 & 3.916748 & 15.50744 & 17.69385 & 16.32648 \\
3 & -279.2150 & 4.855360 & 15.61804 & 18.79829 & 16.80938 \\
4 & -238.9260 & 3.088815 & $14.95331^{*}$ & 19.12738 & 16.51694 \\
\hline
\end{tabular}

Source: Author's calculation

Table 3 shows that the selected information criterion AIC suggests using 4 lags in the model, hence $\mathrm{k}=4$. The variables integration order is determined using the Augmented Dickey-Fuller (ADF) unit root test.

\section{Results and Discussion}

\subsection{Correlation test}

Table 4: Research Variables Correlation Matrix

\begin{tabular}{cccccc}
\hline & EG & PD & BB & GC & EDS \\
\hline EG & 1 & 0.015736 & -0.31751 & 0.687452 & 0.545183 \\
PD & 0.015736 & 1 & -0.357218 & 0.289060 & 0.358343 \\
BB & -0.31751 & -0.357218 & 1 & -0.334127 & -0.701044 \\
GC & 0.687452 & 0.289060 & -0.334127 & 1 & 0.450053 \\
EDS & 0.545183 & 0.358343 & -0.701044 & 0.450053 & 1 \\
\hline
\end{tabular}

Source: Author's calculation

Table 4 shows the correlation coefficients of the research variables. The economic growth is negatively correlated with budget deficit. Thus, it suggests that budget deficit impedes economic growth. High correlations are found between economic growth and government consumption and between budget balance and external debt service with respectively the correlation coefficients of 0.687452 and -0.701044 indicating a strong relationship between economic growth and government consumption and between budget balance and external debt service. The lowest correlation is between economic growth and public debt.

\subsection{Augmented Dickey-Fuller (ADF) unit root test results}

Table 5: Augmented Dickey-Fuller (ADF) Test At Series Level

\begin{tabular}{lcccc}
\hline \multicolumn{1}{c}{ Variables } & $\begin{array}{c}\text { Number of } \\
\text { lag }\end{array}$ & $\begin{array}{c}5 \% \text { Critical } \\
\text { value }\end{array}$ & $\begin{array}{c}\text { ADF test } \\
\text { statistic }\end{array}$ & p_value \\
\hline & & & & \\
EG (economic growth) & 4 & -2.928142 & -0.482070 & 0.8852 \\
PD (public debt) & 4 & -2.928142 & -2.011019 & 0.2812 \\
BB (budget balance) & 4 & -2.928142 & -2.205240 & 0.2073 \\
\hline
\end{tabular}




\begin{tabular}{lcccc}
\hline GC (government & 4 & -2.928142 & -2.461834 & 0.1314 \\
consumption) & 4 & -2.928142 & $-3.603920 *$ & 0.0095 \\
EDS (external debt service) & & & & \\
\hline
\end{tabular}

Source: Author's calculation

Table 5 shows the ADF unit root test on series level. The null hypothesis of unit root in the series is rejected for the variable EDS at 5\% significance level as the ADF test statistic ($3.603920)$ is less than the $5 \%$ critical value $(-2.928142)$ and the $p_{-}$value $(\mathrm{p}=0.0095)$ is lover than 0.05 , that is $\mathrm{p}<0.05$. Hence the variable EDS is stationary at series level. EDS is therefore I(0) integrated of order zero. Table 5 also indicates that the same null hypothesis can't be rejected for all the remaining research variables because their ADF test statistics are greater than the 5\% critical value and their respective probability values are higher than 0.05 . Hence all the remaining 4 variables are nonstationary at their level.

Table 6: Augmented Dickey-Fuller (ADF) Test At Series First Differences

\begin{tabular}{lcccc}
\hline \multicolumn{1}{c}{ Variables } & $\begin{array}{c}\text { Number of } \\
\text { lag }\end{array}$ & $\begin{array}{c}5 \% \text { Critical } \\
\text { value }\end{array}$ & $\begin{array}{c}\text { ADF test } \\
\text { statistic }\end{array}$ & p_value \\
\hline EG (economic growth) & 4 & -2.929734 & -3.160082 & 0.0293 \\
PD (public debt) & 4 & -2.929734 & -3.323846 & 0.0197 \\
BB (budget balance) & 4 & -2.929734 & -3.332286 & 0.0193 \\
GC (government & 4 & -2.929734 & -3.154809 & 0.0297 \\
consumption) & & & & \\
\hline
\end{tabular}

Source: Author's calculation

Table 6 shows the ADF unit root test results on series first differences. The 5\% significance level critical value is -2.929734 . The ADF test statistics for all the variables (EG, PD, BB and GC) are lower than the 5\% critical value and the p_values are less than 0.05 which indicates rejection of the null hypothesis. Hence all the series are stationary they do not have unit root.

According to the ADF unit root tests results, the null hypothesis is rejected at $5 \%$ significance level for the variable EDS but it can't be rejected for the remaining research variables at series level. The same null hypothesis is rejected at $5 \%$ significance level for the remaining variables EG, PD, BB and GC at series' first differences. Therefore EDS is integrated of order zero I(0) and the remaining research variables $\mathrm{EG}, \mathrm{PD}, \mathrm{BB}$ and $\mathrm{GC}$ are integrated of order one $\mathrm{I}(1)$.

\subsection{Bounds Cointegration Test Result}

Having established that the research variables are integrated of different order I(0) and I(1), the appropriate cointegration test is the Bounds test for cointegration proposed by Pesaran, Shin and Smith (2001). The test is conducted at 5\% significance level. Table 7 gives the bounds cointegration test results. 
Table 7: Bounds Cointegration Test Results

$5 \%$ significance level

Critical Value

\begin{tabular}{|c|c|c|c|c|}
\hline Variables & $\begin{array}{l}\text { Lag } \\
\text { length }\end{array}$ & F-statistic & Lower bound $\mathrm{I}(0)$ & Upper bound I(1) \\
\hline EG (economic growth) & 4 & & & \\
\hline PD (public debt) & 4 & & & \\
\hline BB (budget balance) & 4 & & 2.56 & 3.49 \\
\hline GC(gov. consumption) & 4 & 1.407117 & & \\
\hline EDS (ext. debt service) & 4 & & & \\
\hline
\end{tabular}

\section{Source: Author's calculation}

Table 7 shows that the obtained F-statistic of 1.407117 is below the critical values of the lower bounds $\mathrm{I}(0)$ for all the 4 levels of significance $(10 \%, 5 \%, 2.5 \%$ and $1 \%)$ which indicates that there is no cointegration among the research variables, hence, no long-run relationship. Therefore only short run model, the Auto regressive Distributed Lag Model will be considered.

\subsection{ARDL Estimation Result}

The appropriate short run model is the autoregressive distributed lag (ARDL). For the model specification, the Akaike Information criterion selected an ARDL (4, 1, 3, 0, 0). The study will therefore estimate the following equation:

$$
\Delta E G_{t}=\beta_{0}+\sum_{i=1}^{4} \beta_{i} E G_{t-i}+\gamma P D_{t-1}+\sum_{j=1}^{3} \delta_{t} B B_{t-j}+\theta G C_{t}+\rho E D S_{t}
$$

Table 8: ARDL Estimation Results

\begin{tabular}{cccc}
\hline Variable & Coefficient & t-Statistic & Prob. \\
\hline EG (-1) & 0.998431 & 5.769240 & 0.0000 \\
EG (-2) & -0.223659 & -0.879535 & 0.3855 \\
EG (-3) & 0.014587 & 0.058995 & 0.9533 \\
EG (-4) & 0.240901 & 1.410529 & 0.1677 \\
PD & -0.004087 & -1.525370 & 0.1367 \\
PD (-1) & 0.004388 & 1.741871 & 0.0908 \\
BB & 0.003513 & 0.260989 & 0.7957 \\
BB (-1) & 0.012595 & 1.128023 & 0.2674 \\
BB (-2) & 0.006135 & 0.575795 & 0.5687 \\
BB (-3) & 0.022099 & 2.238941 & 0.0320 \\
GC & -0.007810 & -0.666440 & 0.5098 \\
EDS & 0.030692 & 0.834113 & 0.4102 \\
C & -0.866858 & -0.894903 & 0.3773
\end{tabular}

Source: Author's calculation 
Table 8 provides the auto-regressive distributed lag estimation results. Table 8 shows no short run causal effect between public debt and economic growth at 5\% significance level. The same table reveals a run causal effects between public debt and economic growth at $10 \%$ significance level as the probability value ( $p$ ) of the t-statistic of the first lag of public debt (PD(-1)) is less than $0.1 \quad(\mathrm{p}=0.09<0.1)$ but the coefficient is not statistically significant. Table 8 also reveals a short run causal effect between budget balance and economic growth at $5 \%$ level but the coefficient is not significant.

\subsection{Diagnostic Tests on Residuals Results}

In order to check the reliability of the estimates, some diagnostic tests are conducted on the residuals. Table 9, Table 10 and Table 11 give respectively the tests on residuals which include respectively the autocorrelation, the normality and heteroskedasticity test.

Table 9 Residuals Serial Correlation LM Tests

\begin{tabular}{ccc}
\hline LM Statistic & Test statistic & Probability value \\
\hline lag 1 & 27.21109 & 0.0354 \\
$\operatorname{lag} 2$ & 32.35400 & 0.0148 \\
$\operatorname{lag} 3$ & 37.24891 & 0.0447 \\
$\operatorname{lag} 4$ & 19.75268 & 0.0375 \\
\hline
\end{tabular}

Source: Author's calculation

Table 9 shows that the LM statistic for lag 1, lag 2, lag 3 and lag 4. The tests probability values for the 4 lags are less than 0.05. This indicates that the null hypothesis that states that there is no serial correlation among residuals can't be rejected. Hence the residuals are not correlated.

Table 10 Residual Normality Test Result

\begin{tabular}{ccc}
\hline Variables & Jarque-Bera statistics & Probability value \\
\hline EG & 6.786503 & 0.0336 \\
PD & 130.2701 & 0.0000 \\
BB & 0.379482 & 0.0382 \\
GC & 1.497336 & 0.0447 \\
EDS & 0.637874 & 0.0472
\end{tabular}

Source: Author's calculation

Table 10 also shows the residuals normality test result. Looking at Jarque-Bera normality test result, the evidence of normality in the 5 series can't be rejected. Hence the residuals are normally distributed.

Table 11 Residuals Heteroskedasticity Test Result

\begin{tabular}{lll}
\hline LM Statistic & Chi-square & Probability value \\
\hline
\end{tabular}




\begin{tabular}{ccc}
\hline Residual & 233.0490 & 0.0421 \\
Heteroskedasticity Test & & \\
\hline Source: Author's calculation &
\end{tabular}

Source: Author's calculation

Table 11 shows the residual heteroskedasticity test result. The null hypothesis of no heteroskedasticity in the residuals can't be rejected. The residuals are therefore homoskedastics. The diagnostic tests on the residuals showed that the estimates are reliable.

\section{Conclusion and Suggestion}

The present study analyzed the relationship between public debt and economic growth in Niger using annual data for the period 1970-2019. For this analysis, the study used various time series econometric techniques such as unit root test, Bounds cointegration test, auto-regressive distributed lag and some diagnostics tests on residuals. The empirical results showed no long run relationship between public debt and economic growth in Niger. The study also revealed that public debt and budget balance have short run causal effects on economic growth in Niger. The coefficients are significant at $10 \%$ significance level.

\section{Conflict of Interest}

The author of the article declares no conflict of interest.

\section{Funding}

This research study was not funded by any institution. The author conducted the study on his own expenses.

\section{References}

Akaike, H. (1973). Information Theory and an Extension of the Maximum Likelihood Principle. Akademiai Kiado, 267-281.

Dal, D., \& Phillip, A. (2020). External Debt, Domestic Debt and Economic Growth: The Case of Nigeria. Advances in Economics and Business, 8(2), 85-94.

Eneida, P. C. (2018). The Relationship between Public Debt and Economic Growth in Albania and Other Countries. Academic Journal of Interdisciplinary Studies, 7(3), 55-71.

Granger, C. (1988). Some recent development in a concept of causality. Journal of Econometrics, 39(1-2), 199-211.

Irina , B., \& Angela, R. (2014). Interconnections between public indebtedness and inflation in contemporary economies. Recent issues in economic development, 7(4), 59-70.

IMF (2019). Debt sustainability analysis International Monetary Fund, Staff report.

Johansen , S., \& Katarina, J. (1990). Maximum likelihood estimation and inference on cointegration - with applications to the demand for money. Oxford Bulletin of Economics and Statistics, 52(2), 169-210. 
Mhlaba , N., \& Phiri, A. (2017). Is public debt harmful towards economic growth? New evidence from South Africa. Munich Personal RePEc Archive, p. Paper No. 83157.

Muhammad, A., \& Ihtsham, U. (2020). Estimating the Optimal Level of Public Debt for Economic Growth: An Evidence from Pakistan. Quest Journal of Management and Social Sciences, 1(2), 222-232.

Muhammad, D., Ruhaini, M., \& Siti, B. (2017). Real effects of government debt on sustainable economic growth in Malaysia. Journal of International Studies, 10(3), 161-172.

Ndubuisi, P. (2017). Analysis of the Impact of External Debt on Economic Growth in an Emerging Economy: Evidence from Nigeria. African Research Review, 11(4), 156-173.

Peter, C., \& Pierre, B. (1988). Testing for a Unit Root in Time Series Regression. Biometrika. Biometrika, 75(2), 231-254.

Robert, B. (2013). Inflation and economic growth. Annals of economics and finance, 14(1), 85109.

Saifuddin, M. (2016). Public Debt and Economic Growth: Evidence from Bangladesh. Global Journal of Management and Business Research, 16(5).

Siew , P., \& Yan, L. (2015). Public debt and economic growth in Malaysia. Asian Economic and Financial Review, 5(1), 119-126.

Søren, J. (1988). Statistical analysis of cointegration vectors. Journal of Economic Dynamics and Control, , 12(2-3), 231-254.

Stella, S. (2015). The relationship between the government debt and GDP growth: evidence of the Euro area countries. Investment Management and Financial Innovations, 12(1).

World, Bank. (2019). Doing Business Report. World bank report, 143-190. 